\title{
Zinc sulphate induces metallothionein in pancreatic islets of mice and protects against diabetes induced by multiple low doses of streptozotocin
}

\author{
P. Ohly ${ }^{1}$, C. Dohle ${ }^{1}$, J. Abel ${ }^{2}$, J.Seissler ${ }^{1}$, H. Gleichmann ${ }^{1}$ \\ ${ }^{1}$ German Diabetes Centre, German Diabetes Research Institute, Heinrich-Heine University, Düsseldorf, Germany \\ ${ }^{2}$ Division of Toxicology, Medical Institute of Environmental Hygiene, Heinrich-Heine University, Düsseldorf, Germany
}

\begin{abstract}
Aims/hypothesis. Diabetes is induced by multiple low doses of streptozotocin (MLD-STZ) in male mice of susceptible strains. In this model beta-cell injury and T-cell-mediated inflammatory reactions are induced. Probably, reactive oxygen species (ROS) participate in the destruction of beta cells. The effects of ROS can be counterbalanced by several antioxidant systems. One of these is metallothionein (MT), cytosolic proteins that are induced by zinc ions $\left(\mathrm{Zn}^{2+}\right)$ and scavenge hydroxyl radicals ( $\mathrm{OH})$. The effect of $\mathrm{Zn}^{2+}$ on MLD-STZ-diabetes was studied.

Methods. We gave C57BL/6 and $(\mathrm{C} 57 \mathrm{BL} / 6 \times \mathrm{SJL}) \mathrm{F}_{1}$ hybrid mice either MLD-STZ or in addition $\mathrm{Zn}^{2+}$-enriched drinking water. We analysed metallothionein ex vivo in pancreatic islets for protein and mRNA concentration for the isoforms 1 and 2. Pancreatic sections were examined by immunohistochemistry for metallothionein and histologically for insulitis.
\end{abstract}

Results. In both strains, $\mathrm{Zn}^{2+}$-enriched drinking water significantly up-regulated metallothionein and prevented MLD-STZ-diabetes and loss of beta-cell function. In the $\mathrm{F}_{1}$ hybrid mice a variant of MLD-STZ-diabetes was observed. These mice developed hyperglycaemia 10 weeks after the first injection of STZ (in contrast to 2 weeks observed in other mouse strains) and pronounced insulitis. The mRNA of the metallothionein isoforms 1 and 2 were constitutively expressed and slightly up-regulated by $\mathrm{Zn}^{2+}$-enriched drinking water. All islets cells stained for metallothionein.

Conclusions/interpretations. Drinking water enriched with $\mathrm{Zn}^{2+}$ significantly up-regulated metallothionein production in pancreatic islets of mice and prevented diabetes induced with MLD-STZ. [Diabetologia (2000) 43: 1020-1030]

Keywords Streptozotocin, metallothionein, zinc sulphate, diabetes, beta cells
T cell-mediated inflammatory autoimmune reactions are considered to cause Type I diabetes (insulin-dependent) mellitus $[1,2]$. Reactive oxygen species

Received: 22 February 2000 and in revised form: 10 April 2000

Corresponding author: Dr. P. Ohly, Deutsches Diabetes-Forschungsinstitut, Auf'm Hennekamp 65, D-40225 Düsseldorf, Germany

Abbreviations: AEC, 3-Amino-9-ethylcarbazole; B6SJL/ $\mathrm{F}_{1}$, $(\mathrm{C} 57 \mathrm{BL} / 6 \times \mathrm{SJL}) \mathrm{F}_{1}$ male hybrids; $\mathrm{Fe}^{2+}$, iron; HBSS, Hank's balanced salt solution; M, DNA molecular weight marker; MLD-STZ, multiple low doses of streptozotocin; MT, metallothionein; N, negative control; $\mathrm{NO}$, nitrogen monoxide; $\mathrm{O}_{2}{ }^{--}$, superoxide radical; $\mathrm{OH}$, hydroxyl radical; $\mathrm{ROS}$, reactive oxygen species; SOD, superoxide dismutase; $\mathrm{Zn}^{2+}$, zinc sulphate
(ROS) and nitrogen monoxide (NO') contribute to inflammatory diseases [3] and are implicated as mediators of beta-cell destruction in animal models of diabetes [4-11]. Reactive oxygen species are continuously produced by respiring mitochondria [12] and reduced nicotinamide adenine dinucleotide phosphate oxidase [13]. Certain antioxidants specifically protect against their damage: superoxide dismutase (SOD) against superoxide radical $\left(\mathrm{O}_{2}{ }^{-}\right)$, catalase against hydrogen peroxide $\left(\mathrm{H}_{2} \mathrm{O}_{2}\right)$, and glutathione peroxidase against $\mathrm{H}_{2} \mathrm{O}_{2}$ and lipid peroxides. It is, however, not known if there is a specific defense against hydroxyl radicals $(\mathrm{OH})$ in vivo, the most strongly reactive of ROS [14].

Recently, very low concentrations of antioxidants were found in isolated pancreatic islets of rats and in 
insulin-producing RINm5F cells compared with other rat tissues [15]. The authors concluded that beta cells are vulnerable to ROS because of their poor antioxidant system. This assumption was corroborated by the observation that up-regulation of catalase and glutathione peroxidase in transfected RINm5F cells conferred resistance to ROS [16]. Furthermore, overexpression of copper/zinc $(\mathrm{Cu} / \mathrm{Zn}) \mathrm{SOD}$ in transgenic mice [17] or targeted to beta cells [18] averted attacks on beta cells by ROS generated by streptozotocin (STZ) or alloxan or both.

Metallothionein (MT) are a group of low molecular weight (approximately $7000 \mathrm{M}_{\mathrm{r}}$ ), cysteine-rich (23-33 mol\% ) cytosolic proteins found in all eukaryotic species [19]. Metallothionein are potent $\mathrm{OH}$ scavengers in vitro $[14,20-22]$ and 38.5-fold to 50fold more effective in protecting DNA from $\mathrm{OH}$ attacks than glutathione $[23,24]$. There are four isoforms of MT [25]. The isoforms MT-1 and MT-2 are present in major organs, MT-1 being more abundant than MT-2 [19, 26]. Metallothionein synthesis is stimulated by numerous non-metallic agents and by metal ions $[14,19]$. In rats and mice, $\mathrm{Zn}$ salt-induced MT were localized in the cytoplasm of pancreatic exocrine cells [26-31]. In rats, islets stained uniformly for MT by immunohistochemistry [26] but in mice the results were discrepant. By immunohistochemistry, an antibody reacting with both MT-1 and MT-2 isoforms failed to stain islets of normal and of transgenic mice overexpressing MT-1 [31]. Our laboratory applying quantitative measurements [32] found, however, constitutive concentrations and induction of MT with $\mathrm{Zn}$ sulphate $\left(\mathrm{Zn}^{2+}\right)$ in islets of mice in vitro [33] and ex vivo [34].

Pretreatment with $\mathrm{Zn}^{2+}$ prevents diabetes in animals. In rats, s. c. injection of $\mathrm{Zn}^{2+}$ reduced hyperglycaemia induced with one toxic dose of STZ injected i.p. [30]. Our laboratory reported that i. p. pretreatment with $\mathrm{Zn}^{2+}$ prevented diabetes induced with multiple low doses of streptozotocin (MLD-STZ) in mice [35]. Both groups of investigators proposed that $\mathrm{Zn}^{2+}$ induced MT scavenged OH triggered by STZ. Further support for the protective effect of $\mathrm{Zn}^{2+}$ on MLD-STZ-induced diabetes in mice is presented.

\section{Materials and methods}

Animals. We obtained C57BL/6 male mice at 5-6 weeks of age from Harlan Winkelmann (Borchen, Germany) and purchased $(\mathrm{C} 57 \mathrm{BL} / 6 \times \mathrm{SJL}) \mathrm{F}_{1}$ male hybrids $\left(\mathrm{B} 6 \mathrm{SJL} / \mathrm{F}_{1}\right)$ at 5-6 weeks of age from The Jackson Laboratories (Bar Harbor, Me., USA). Mice were 7-8 weeks old at the beginning of the experiments. They were kept under specific pathogen-free conditions, received a rodent diet (Ssniff M, Ssniff, Soest, Germany) and had free access to drinking water. The animal studies were conducted in accordance with the "Principles of laboratory animal care" (NIH publication no. 85-23, revised 1995) as well as the current version of the German Law on the Protection of Animals.
Reagents. Collagenase (0.42 U/mg), HEPES, bovine haemoglobin and TRIS were supplied by Serva (Heidelberg, Germany) and reagents for the Krebs-Ringer buffer, $\mathrm{ZnSO}_{4}$, haematoxylin and Kaiser's glycerol gelatin by Merck (Darmstadt, Germany). Streptozotocin was obtained from Roche Diagnostics (Mannheim, Germany), D-glucose, BSA, and RPMI 1640 culture medium without D-glucose from Sigma (Deisenhofen, Germany), FCS, Hank's balanced salt solution (HBSS), PBS and Penicillin-Streptomycin were supplied by Gibco BRL (Eggenstein, Germany). Lymphocyte separation medium was purchased from Biochrom (Berlin, Germany), carrier-free ${ }^{109}$ cadmium (Cd) was obtained from Amersham Buchler (Braunschweig, Germany), Bio-Rad dye solution from Bio-Rad (München, Germany), insulin RIA 100 from Pharmacia \& Upjohn (Freiburg, Germany) and anti-GAD-RIA from BRAHMS Diagnostica (Berlin, Germany). For staining by immunohistochemistry, guinea pig antiserum to porcine insulin, rabbit anti-guinea pig $\mathrm{IgG}$, goat anti-rabbit IgG, normal serum of guinea pigs and rabbits, substrate 3-amino-9-ethylcarbazole (AEC) and washing solutions were supplied by Dako (Hamburg, Germany). Polyclonal antiserum to rat liver MT-1 and MT-2 was generated in rabbits and kindly provided by Dr. K. H. Summer (Institute of Toxicology, Neuherberg, Germany).

Treatment of mice. To investigate whether $\mathrm{Zn}^{2+}$-enriched drinking water induces MT synthesis in pancreatic islets, groups of five mice each had free access to water enriched with $25 \mathrm{mmol} / 1 \mathrm{Zn}^{2+}$ for 1 week [25]. Mice whose water had no additive served as controls. Islets were isolated from individual mice [34] and prepared for measurement of MT concentrations [33].

To induce diabetes, mice were injected i.p. with $5 \times 40 \mathrm{mg}$ STZ/kg body weight on each of 5 consecutive days according to the MLD-STZ protocol [36]. Streptozotocin was dissolved in $0.1 \mathrm{~mol} / \mathrm{l}$ sodium citrate buffer $(\mathrm{pH} 4.0)$ at a concentration of $0.4 \%$ and injected within $5 \mathrm{~min}$ after preparation. The day of the first STZ injection was designated day 0. For treatment with $\mathrm{Zn}^{2+}$, two protocols were applied. In the first protocol groups of $\mathrm{C} 57 \mathrm{BL} / 6$ and $\mathrm{B} 6 \mathrm{SJL} / \mathrm{F}_{1}$ mice were given free access to drinking water enriched with $25 \mathrm{mmol} / 1 \mathrm{Zn}^{2+}$; this treatment was started 1 week before the first STZ injection and conducted throughout the whole experimental period until the mice were killed. In the second protocol C57BL/6 mice were given free access to $\mathrm{Zn}^{2+}$-enriched drinking water from 1 week before the first STZ injection until 1 day after the last STZ injection. Groups of mice that had only received either $\mathrm{Zn}^{2+}$-enriched drinking water or i.p. injections of MLD-STZ served as controls. The $\mathrm{Zn}^{2+}$-enriched drinking water was freshly prepared and replaced daily.

For the OGTT, D-glucose was dissolved in $0.9 \%$ saline at a concentration of $20 \%$. After a fasting period of $16 \mathrm{~h}$, each mouse received an oral load of $2.0 \mathrm{~g}$ D-glucose $/ \mathrm{kg}$ body weight through an intubation tube. Blood glucose concentrations were measured just before $(0 \mathrm{~min})$ and at 15 and $30 \mathrm{~min}$ after the glucose challenge. The C57BL/6 mice underwent an OGTT at week 4 and B6SJLF 1 at week 6 after the onset of treatment with MLD-STZ. Mice matched with them for age served as controls.

Determination of plasma glucose. Blood samples were collected weekly from non-fasted animals between 0900 and 1100 hours from the retro-orbital venous plexus, using $20 \mu \mathrm{l}$ capillary glass tubes. Glucose concentration was measured by the hexokinase method using an autoanalyser (Eppendorf APC 5040, Hamburg, Germany). Hyperglycaemia was defined as a blood glucose concentration of $13.9 \mathrm{mmol} / \mathrm{l}$ or more persisting for 3 or more consecutive weeks. 
Determination of MT. Metallothionein were measured by the ${ }^{109} \mathrm{Cd}$-haemoglobin saturation assay as described previously $[32,34]$. Briefly, isolated islets from individual mice were washed three times with PBS, covered with $50 \mu$ l double-distilled water and stored at $-80^{\circ} \mathrm{C}$. For measurement of total protein and MT in cytosolic preparations, the deep-frozen islets were thawed, kept at $4{ }^{\circ} \mathrm{C}$, lyophilised and resuspended in $300 \mu \mathrm{l}$ TRIS/HCl $(10 \mathrm{mmol} / 1,85 \mathrm{mmol} / \mathrm{l} \mathrm{NaCl}, \mathrm{pH} 7.4)$. After centrifugation $\left(1000 \mathrm{~g}, 5 \mathrm{~min}, 4^{\circ} \mathrm{C}\right), 100 \mu \mathrm{l}$ of the supernatant were used for total protein measurement by Bio-Rad protein assay and $200 \mu \mathrm{l}$ were kept at $-80^{\circ} \mathrm{C}$ until measurement of MT. To quantify concentrations of total $\mathrm{MT},{ }^{109} \mathrm{Cd}$ was added in excess to $100 \mu \mathrm{l}$ of the cytosolic probes. To recover ${ }^{109} \mathrm{Cd}$ bound to MT, excess ${ }^{109} \mathrm{Cd}$ was complexed by addition of bovine haemoglobin $(4 \%)$ and the Cd-haemoglobin complex was removed by heat treatment. After centrifugation $\left(4000 \mathrm{~g}, 5 \mathrm{~min}, 20^{\circ} \mathrm{C}\right)$ the supernatant containing MT was analysed for ${ }^{109} \mathrm{Cd}$ with a Packard Auto-Gamma 5780 (Packard, Frankfurt/Main, Germany). Addition of the haemolysate and heat treatment were repeated three times. The calculation of MT content was based on a molar ratio of $7 \mathrm{~g}$-atom $\mathrm{Cd} / \mathrm{mol} \mathrm{MT}$ [37] and a molecular weight of 6600 .

Immunohistochemistry. After the mice had been killed by cervical dislocation, the pancreas and liver were removed and specimens were snap-frozen in liquid nitrogen. Cryostat sections $(5 \mu \mathrm{m}$ thick) were placed on slides, air dried, acetonefixed for $10 \mathrm{~min}$, and stained for either MT or insulin by using an immunoperoxidase method. A polyclonal rabbit anti-rat MT antiserum, cross-reacting with mouse MT was used for staining of MT. Sections were overlayed with $50 \mu \mathrm{l}$ of the primary antibody to rat MT (diluted 1:100) and incubated for $30 \mathrm{~min}$ at room temperature in a humid chamber. After two washing procedures in PBS, the sections were incubated with $50 \mu \mathrm{l}$ of peroxidase-conjugated goat anti-rabbit IgG antibody (diluted 1:100) for $45 \mathrm{~min}$ at room temperature and washed twice with PBS. The staining reaction was activated by incubation of the sections with the substrate solution AEC for $20 \mathrm{~min}$ at $37^{\circ} \mathrm{C}$ then stopped by thorough washings in distilled water. Finally, the sections were counterstained with Mayer's haemalaun and mounted in Kaiser's glycerol gelatin. Controls for the immunohistochemical staining were incubated with non-immune serum of the animal species used to produce the primary antibodies and omission of the primary antibody reagents from the procedure. Microscopical examinations were done independently by two of the authors. The degree of staining was scored as follows: $0=$ no staining; $1+=$ dots of staining loosely scattered throughout the cell cytoplasm; $2+=50 \%$ staining of the cytoplasm; $3+=$ more than $75 \%$ staining of the cytoplasm.

Histological examination. For light microscopy, groups of 5 $\mathrm{B} 6 \mathrm{SJL} / \mathrm{F}_{1}$ mice each were killed on day 10 as well as 4 weeks after the first injection of MLD-STZ. Sections from untreated mice and mice treated with $\mathrm{Zn}^{2+}$-enriched drinking water served as controls. Preparation of pancreas sections, staining and examination were done as described previously with slight modifications [38]. Briefly, the pancreata were removed and fixed in Bouin's solution. After routine processing, three stepsections $5 \mu \mathrm{m}$ thick at a distance of $50 \mu \mathrm{m}$ were prepared from each paraffin-blocked pancreas and sections were stained with haematoxylin-eosin. After the slides were coded, examination of the sections for the presence of infiltrates with mononuclear cells at both islet-pole and intra-islet sites were done independently by two of the authors. The degree of intra-islet infiltrates (insulitis) was scored as follows: $0=$ no infiltrate; $1+=$ mild infiltrate $(\leq 30 \%$ of islet cells are mononuclear cells); $2+=$ moderate infiltrate ( $>30$ to $\leq 75 \%$ of islet cells
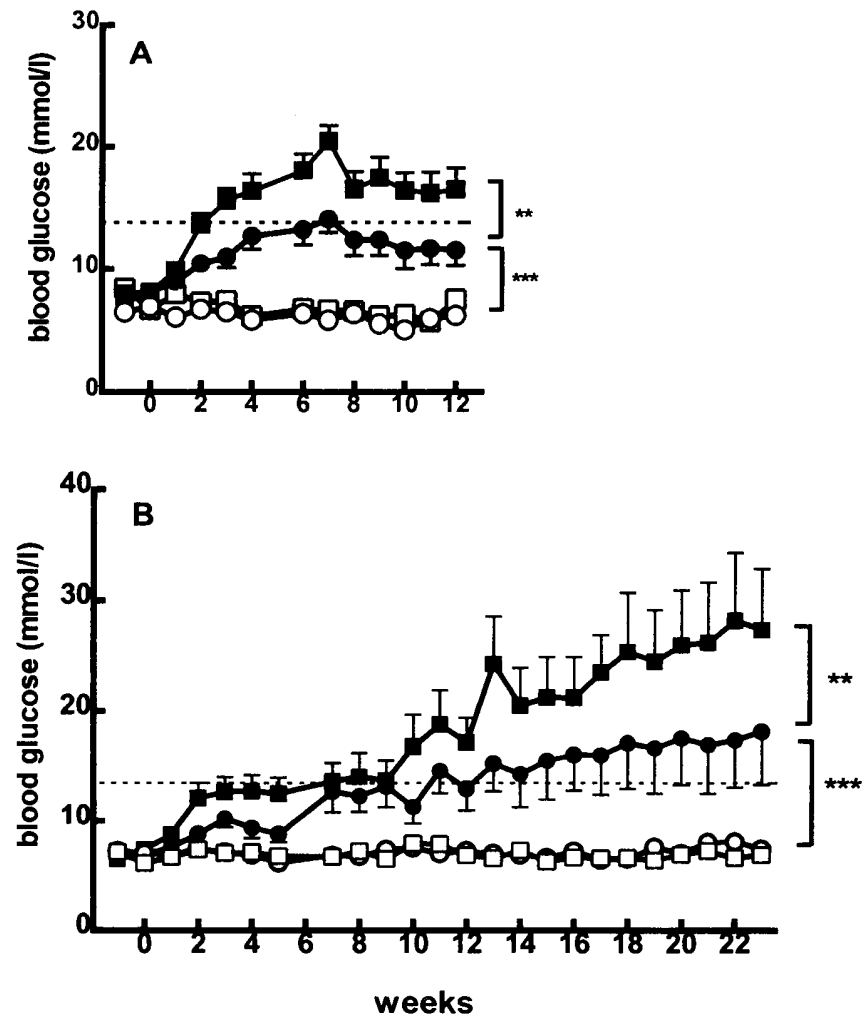

Fig. 1A, B. Effect of $\mathrm{Zn}^{2+}$-enriched drinking water on diabetes induced by MLD-STZ in C57BL/6 $\mathbf{A}$ and $\mathrm{B} 6 \mathrm{SJL} / \mathrm{F}_{1} \mathbf{B}$ mice. Blood glucose concentrations (means \pm SEM) over time in weeks are shown. Bars of very small SEM are hidden in the curves symbols. Male mice were treated with either MLDSTZ only (ם), MLD-STZ plus $\mathrm{Zn}^{2+}$-enriched $(25 \mathrm{mmol} / \mathrm{l})$ drinking water $(\mathbf{O}), \mathrm{Zn}^{2+}$-enriched drinking water only $(\bigcirc)$ or were not treated $(\square)$. Each group treated with MLD-STZ consisted of 10-15 mice and for the control groups 5 mice each were used. $\mathrm{Zn}^{2+}$-enriched drinking water prevented hyperglycaemia induced with MLD-STZ. ** $p<0.01$ comparing the areas under the curves of MLD-STZ-treated vs MLDSTZ-treated plus $\mathrm{Zn}^{2+}$-treated groups; $* * * p<0.001$ comparing the areas under the curves of MLD-STZ- plus $\mathrm{Zn}^{2+}$-treated vs control groups

are mononuclear cells); $3+=$ severe infiltrate $(>75 \%$ islet cells are mononuclear cells). Perivascular or periductular sites or both at islet poles were examined for absence or presence of infiltrates.

Determination of $G A D_{65}$-autoantibodies. Samples of sera from 6 untreated and 20 mice treated with MLD-STZ were analysed for $\mathrm{GAD}_{65}$-autoantibodies using a radioligand assay as described previously [39]. The cut-off was defined at $571 \mathrm{cpm}$.

$R N A$ preparation and $R T-P C R$. Total RNA was extracted from pooled islets isolated from groups of ten mice each and from liver tissue using the TRIzol reagent kit (Life Technologies, Gaithersburg, Md., USA) [40]. The RNA preparation was stored at $-80^{\circ} \mathrm{C}$ until use. By using Moloney murine leukemia virus RT (Life Technologies), $1 \mu \mathrm{g}$ of total RNA from islets and liver were reversibly transcribed into cDNA, followed by amplification of target genes by PCR [41]. For amplification of mouse MT-1, MT-2 and the housekeeping gene $\beta$-actin as internal control, primer pairs were commercially synthesized by 
MWG-Biotech (Ebersberg, Germany): MT-1, 5'-TCCTGAGTACCTTCTCCTC-3', 3'-GGTGGTGCACATTTATCAT-5'; MT-2, 5'-TGCGCTGGCGCCTGCAAAT-3', 3'-TCTCCGAAGGCTGTTCACG-5'; proinsulin, 5'-GGCTTCTTCTACACACACCCA-3', 3'-ATGGTCGACCTCTTGATGAC-5'; $\beta$ actin, 5'-GTGGGCCGCTCTAGGCACCAA-3', 3'-CTCTTTGATGTCACGCACGATTTC-5'. The RT reaction was amplified using Taq polymerase (Roche Diagnostics, Mannheim, Germany). The cycle numbers were chosen to be on the linear, i.e. exponential phase of the amplification of the three genes: 35 for MT-1 and MT-2, 26 for proinsulin and 30 for $\beta$-actin. For separation, the amplified PCR products, $7 \mu$ l of each, i.e. the target product and $\beta$-actin, were loaded on $1.5 \%$ agarose gels containing ethidium bromide $(0.1 \mu \mathrm{g} / \mathrm{ml})$. The resulting bands were photographed with Polaroid Instant Pack Film 665 (Polaroid, Cambridge, Mass., USA). To exclude the possibility of genomic DNA contamination during RNA preparation, negative controls were set up for each PCR amplification, using purified RNA as a template.

Data analysis. Data presented are means \pm SEM or SD. For PCR, intensities of bands of PCR products on the film were determined using scanning densitometry. The ratio of the intensity integral of target PCR products to that of $\beta$-actin was calculated. Comparisons between groups were done by the unpaired Student's $t$ test. We considered $p$ less than 0.05 statistically significant.

\section{Results}

Prevention of MLD-STZ-induced diabetes by $\mathrm{Zn}^{2+}$. Treatment with $\mathrm{Zn}^{2+}$-enriched drinking water prevented diabetes induced by MLD-STZ in both C57BL/6 and B6SJL/F mice (Fig.1). The C57BL/ 6 mice that were treated with MLD-STZ only started to develop hyperglycaemia 2 weeks after the first injection of STZ and hyperglycaemia persisted for the further observation period of 10 weeks. Treatment with $\mathrm{Zn}^{2+}$-enriched drinking water, however, significantly reduced the high blood glucose concentrations induced by MLD-STZ. Although the mean blood glucose concentrations in this group did not exceed the euglycaemic threshold of $13.9 \mathrm{mmol} / \mathrm{l}$ they were significantly higher compared with the values measured in the two control groups which were treated with either $\mathrm{Zn}^{2+}$-drinking water or tap water alone (Fig. 1). Treatment with $\mathrm{Zn}^{2+}$-enriched drinking water until 1 day after the last injection of STZ did not suffice to protect against MLD-STZ-induced hyperglycaemia (data not shown).

Notably, B6SJL/F $\mathrm{F}_{1}$ mice started to develop severe hyperglycaemia just 10 weeks after the first injection of STZ. Treatment with $\mathrm{Zn}^{2+}$-enriched drinking water significantly reduced the high blood glucose concentrations induced by MLD-STZ during the observation period of 23 weeks. Yet, in this group, the mean blood glucose concentrations slightly exceeded the euglycaemic threshold of $13.9 \mathrm{mmol} / \mathrm{l}$ and they remained significantly higher than those in the two control groups that had either not been treated or had re-
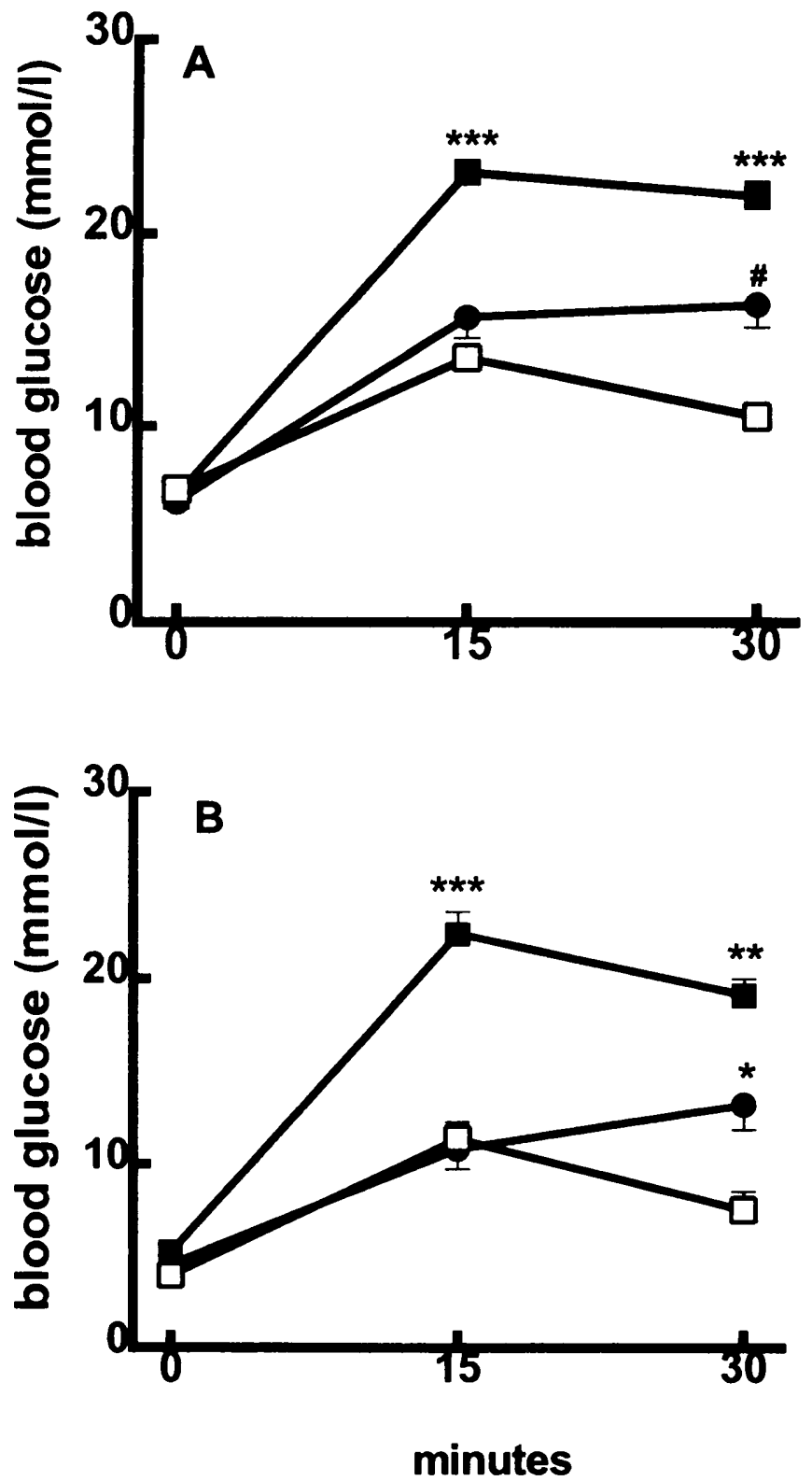

Fig. 2A, B. Effect of continous treatment with $\mathrm{Zn}^{2+}$-enriched drinking water on oral glucose tolerance in mice treated with MLD-STZ. Blood glucose concentrations (means \pm SEM) before and after a glucose load are given. Bars of very small SEM are hidden in the curves symbols. A 4 weeks after starting treatment of C57BL/6 mice. B 6 weeks after starting treatment of B6SJL/ $F_{1}$ mice. Mice were treated with MLD-STZ either alone $(\boldsymbol{\square})$ or in addition with $\mathrm{Zn}^{2+}$-enriched $(25 \mathrm{mmol} / \mathrm{l})$ drinking water $(\bullet)$ or were not treated $(\square)$. Groups of 15 mice each were used for the treatment with MLD-STZ and groups of 5 mice each for controls. $\mathrm{Zn}^{2+}$-enriched drinking water prevented loss of glucose tolerance induced with MLDSTZ. $* * p<0.01$ and $* * * p<0.001$ comparing MLD-STZtreated vs MLD-STZ- plus $\mathrm{Zn}^{2+}$-treated groups; * $p<0.05$ and $^{\#} p<0.001$ comparing MLD-STZ- plus $\mathrm{Zn}^{2+}$-treated vs untreated control groups 
Table 1. Effect of $\mathrm{Zn}^{2+}$-enriched drinking water on the variables indicated

\begin{tabular}{|c|c|c|c|c|}
\hline \multirow[t]{2}{*}{ Variable } & \multicolumn{2}{|c|}{ C57BL/6 mice } & \multicolumn{2}{|l|}{ B6SJL/F ${ }_{1}$ mice } \\
\hline & $\overline{\mathrm{Zn}^{2+}}$ & control & $\overline{\mathrm{Zn}^{2+}}$ & control \\
\hline 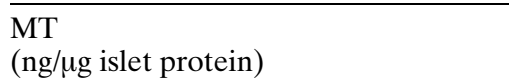 & $1.34 \pm 0.26^{\mathrm{a}}$ & $0.61 \pm 0.11$ & $2.20 \pm 0.34^{\mathrm{b}}$ & $0.35 \pm 0.05$ \\
\hline Body weight $(\mathrm{g})$ & $23.5 \pm 0.7$ & $22.2 \pm 0.3$ & $25.2 \pm 0.3$ & $25.8 \pm 0.4$ \\
\hline Blood glucose concentration (mmol/l) & $7.2 \pm 0.3$ & $8.3 \pm 0.5$ & $7.5 \pm 0.3$ & $6.7 \pm 0.2$ \\
\hline Islets/mouse $(n)$ & $124 \pm 6$ & $135 \pm 10$ & $130 \pm 11$ & $142 \pm 7$ \\
\hline Total protein concentration/Islet (ng) & $88.6 \pm 4.9$ & $78.6 \pm 5.5$ & $153.30 \pm 24.11$ & $194.93 \pm 31.03$ \\
\hline
\end{tabular}

Mice were treated with $\mathrm{Zn}^{2+}$-enriched drinking water or tap water (control) for 1 week. Results were obtained from groups of four to five $\mathrm{C} 57 \mathrm{BL} / 6$ and nine to ten $\mathrm{B} 6 \mathrm{SJL} / \mathrm{F}_{1}$, hybrid mice each. Data are means \pm SEM. ${ }^{\mathrm{a}} p<0.05 ;{ }^{\mathrm{b}} p<0.001$ compared with untreated controls ceived $\mathrm{Zn}^{2+}$-enriched drinking water only (Fig.1). The protective effect induced by $\mathrm{Zn}^{2+}$ was not caused by starving because the body weight and the individual daily intake of approximately $7 \mathrm{ml}$ water contain-

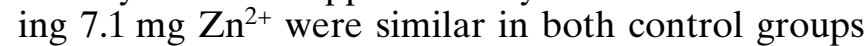
(data not shown). Note that it has been proved that $\mathrm{Zn}^{2+}$ is essentially non-toxic in human. It is neither carcinogenic, mutagenic nor teratogenic [42]. Because hyperglycaemia determines the intake of water the individual consumption was not calculated. Nevertheless, the protective effect of $\mathrm{Zn}^{2+}$ was exerted before diabetes developed.

$\mathrm{Zn}^{2+}$-enriched drinking water prevented essential betacell dysfunction in mice injected with MLD-STZ. In vivo, beta-cell function was assessed by using the OGTT. As expected, the groups in mice injected with MLD-STZ had a high glucose tolerance at 15 and $30 \mathrm{~min}$ after the glucose load compared with the untreated control groups (Fig.2). Treatment with $\mathrm{Zn}^{2+}$-enriched drinking water, however, significantly countered MLD-STZ-induced loss of glucose tolerance. At week 4 after the first injection of STZ, C57BL/6 mice showed only slightly reduced glucose tolerance similar to the results obtained at week 6 in B6SJL/F 1 mice (Fig. 2).

$\mathrm{Zn}^{2+}$-enriched drinking water induced MT in pancreatic islets. Treatment of $\mathrm{C} 57 \mathrm{BL} / 6$ and $\mathrm{B} 6 \mathrm{SJL} / \mathrm{F}_{1}$ mice with $\mathrm{Zn}^{2+}$-enriched drinking water for 1 week resulted in significant induction of MT synthesis in pancreatic islets, as measured by the ${ }^{109} \mathrm{Cd}$-haemoglobin assay (Table 1). Metallothionein were measured in islets isolated from individual mice from groups of five $\mathrm{C} 57 \mathrm{BL} / 6$ and ten $\mathrm{B} 6 \mathrm{SJL} / \mathrm{F}_{1}$ donors. The index of MT induction, i.e. the ratio of MT concentrations in islets from mice treated with $\mathrm{Zn}^{2+}$-enriched drinking water over that of untreated control mice, was $2.3 \pm 0.5$ in $\mathrm{C} 57 \mathrm{BL} / 6$ mice and $7.5 \pm 1.6$ in $\mathrm{B} 6 \mathrm{SJL} / \mathrm{F}_{1}$ mice.

The $\mathrm{Zn}^{2+}$-enriched drinking water was well tolerated. Mice thus treated failed to show any pathological signs or symptoms as judged by clinical inspection and several laboratory variables, such as body weight, blood glucose concentrations, number of pancreatic islets isolated and total protein concentrations/pancreatic islet (Table 1).

Localization of pancreatic MT by immunohistochemistry. Metallothionein proteins were clearly localized in the cytoplasm of pancreatic islets. The islets in snap-frozen pancreatic sections prepared from untreated C57BL/6 control mice stained uniformly for MT (Fig.3). Pancreatic sections of 11 untreated C57BL/6 donors were prepared and of the 76 islets examined the intensity of staining was as follows: $1+=0 \%, 2+=52.5 \%$ and $3+=47.5 \%$; staining of the exocrine pancreatic cells was considerably less and was scored as follows: $1+=86.0 \%, 2+=14 \%$, and $3+=0 \%$. Similar results were obtained in pancreatic sections that were prepared on day 8 after starting treatment with either $\mathrm{Zn}^{2+}$-enriched drinking water alone, on day 6 after starting treatment with MLD-STZ alone or on day 6 after starting treatment with MLD-STZ plus $\mathrm{Zn}^{2+}$-enriched drinking water (data not shown). Thus, the statistically significant ex vivo increment of MT protein in isolated islets of mice treated with $\mathrm{Zn}^{2+}$-enriched drinking water (Table 1) was not indicated by immunohistochemistry, a method which is not unequivocally suitable for quantitative analysis. No staining was detected when sections were incubated with non-immune serum of rabbits (Fig. 3) or when the primary antibody was omitted from the procedure (data not shown). The presence of beta cells in the islets was confirmed by staining with guinea pig anti-porcine insulin antibody as primary reactant (data not shown). The results obtained in parallel or serial sections were indistinguishable.

Modest increase of mRNA expression of MT-1 and MT-2 by $\mathrm{Zn}^{2+}$-enriched drinking water. The mRNA of the MT isoforms MT-1 and MT-2 were constitutively expressed in pancreatic islets and liver of both C57BL/6 and B6SJL/F $F_{1}$ mice (Fig.4). The density of MT-1 mRNA considerably exceeded that 

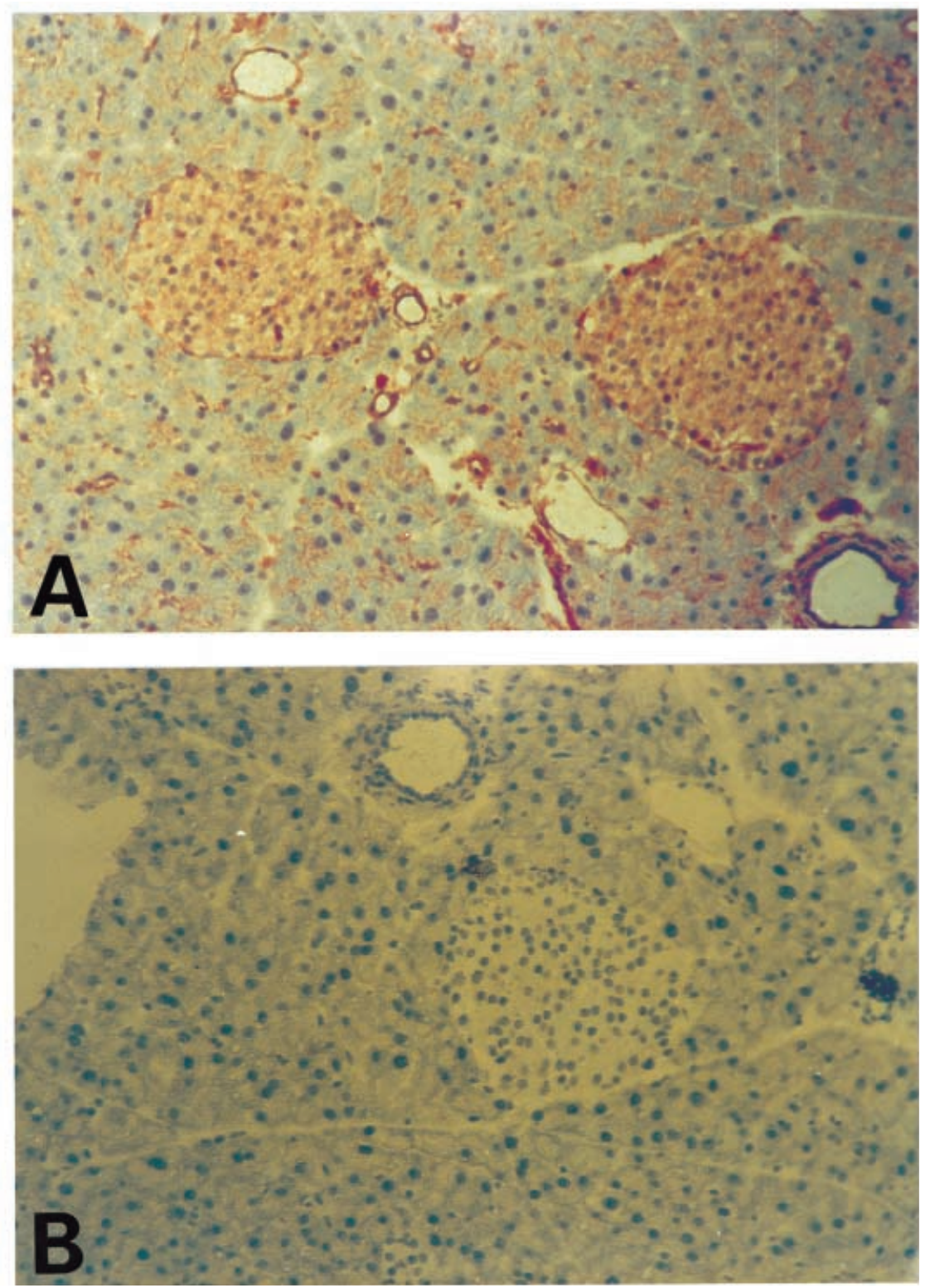

Fig. 3 A, B. Immunohistochemical staining of MT in pancreatic sections of untreated male C57BL/6 mice. A uniform staining for MT, scored $3+$, of islet cells and weak staining, scored $1+$, of exocrine cells. B no staining of the section with non-immune serum of rabbits. Original magnification $\times 400$

of MT-2 mRNA in both tissues. Treatment of mice with $\mathrm{Zn}^{2+}$-enriched drinking water modestly increased the density of both MT-1 and MT-2 mRNA expression in pancreatic islets as well as in liver tissue (Fig. 5). A statistically significant increment was only observed for MT-1 mRNA in pancreatic islets of $\mathrm{B} 6 \mathrm{SJL} / \mathrm{F}_{1}$ mice.

$\mathrm{Zn}^{2+}$-enriched drinking water failed to affect the $m R$ $N A$ expression of proinsulin. We tested if the protective effect of $\mathrm{Zn}^{2+}$-enriched drinking water against hyperglycaemia induced by MLD-STZ resulted from an increment of proinsulin. Similar density of proinsulin mRNA expression was found in islets prepared from $\mathrm{C} 57 \mathrm{BL} / 6$ mice treated with $\mathrm{Zn}^{2+}$-enriched drinking water and in islets isolated from untreated controls (Fig.6). Similar results were also obtained in islets of $\mathrm{B} 6 \mathrm{SJL} / \mathrm{F}_{1}$ mice (data not shown).

$M L D$-STZ-induced insulitis in B6SJL/F $/ F_{1}$ mice. Histological examination of pancreatic sections were done to test if treatment of $\mathrm{B} 6 \mathrm{SJL} / \mathrm{F}_{1}$ mice with MLDSTZ also stimulates immune reactions with infiltration of islets by mononuclear cells similar to other inbred strains such as CD-1 [36] and C57BL/6 [38]. Inflammatory infiltrates were observed at numerous islet poles and intra-islet sites. As measured against a scoring system from 0 to $3+, \mathrm{Zn}^{2+}$-enriched drinking water failed to essentially change the degree of insulitis [38]. Insulitis was absent in untreated mice and 
A

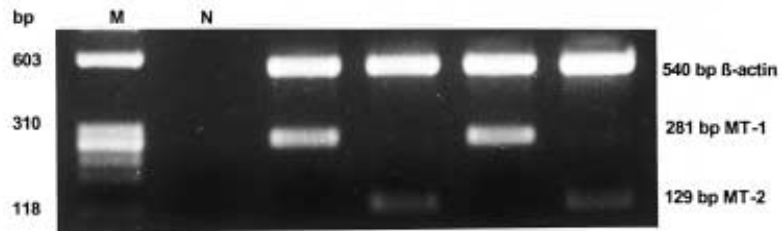

B

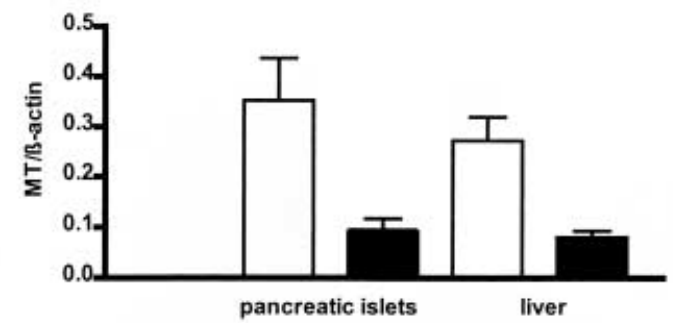

$C$ bp $\mathrm{M} N$

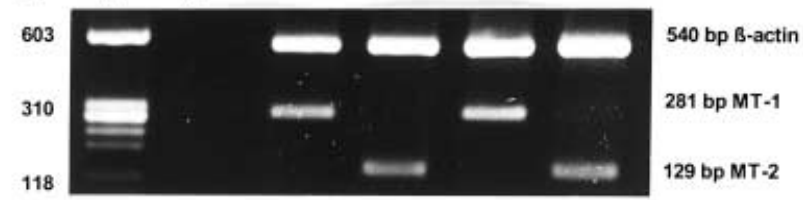

D

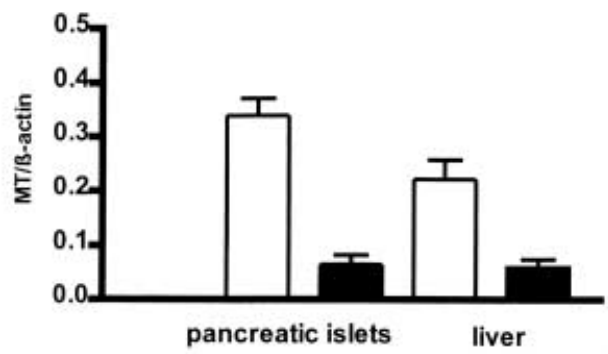

Fig. 4A-D. RT-PCR determination of MT-1, MT- 2 and $\beta$-actin mRNA in isolated pancreatic islets and liver of C57BL/6 $\mathbf{A}$ and B6SJL/F $/ F_{1} \mathbf{C}$ mice. Means \pm SEM of the ratios of MT-1 ( $\square)$ to $\beta$-actin and MT-2 (ם) to $\beta$-actin mRNA of C57BL/6 $\mathbf{B}$ and $\mathrm{B} 6 \mathrm{SJL} / \mathrm{F}_{1}$ D. The values were calculated from three independent experiments. MT-1 and MT-2 mRNA are constitutively expressed in pancreatic islets; MT- 1 mRNA expression is dominant over that of MT-2. A similar pattern of MT-1 and MT-2 mRNA expression was detected in the liver tissue

rarely visible in mice treated with $\mathrm{Zn}^{2+}$-enriched drinking water (Table 2, Fig. 7).

MLD-STZ failed to induce $G A D_{65}$-autoantibodies in $B 6 S J L / F_{1}$ mice. As $\mathrm{B} 6 \mathrm{SJL} / \mathrm{F}_{1}$ mice showed pronounced insulitis we wanted to evaluate whether the intense immune reactivities induce production of autoantibodies to diabetes-associated antigens [43]. Therefore, sera of mice were analysed for $\mathrm{GAD}_{65}$-autoantibodies at different time points after treatment. The concentrations of $\mathrm{GAD}_{65}$-autoantibodies (means $\pm \mathrm{SD}$ ) were $355 \pm 54 \mathrm{cpm}$ in untreated control mice. The concentrations after 10 days, 4 weeks and 10 weeks of treatment with MLD-STZ were $388 \pm 67,477 \pm 103$ and $561 \pm 233$, respectively. Treat-
A

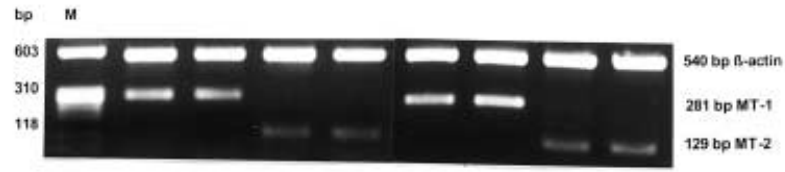

B

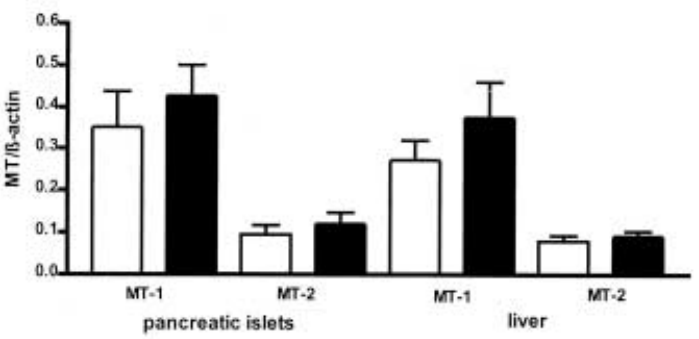

C bp $M$

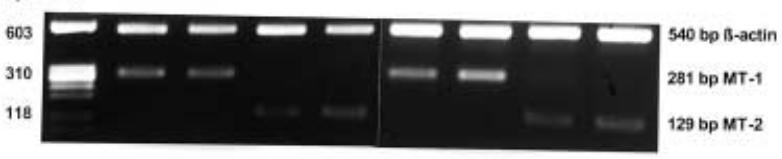

D

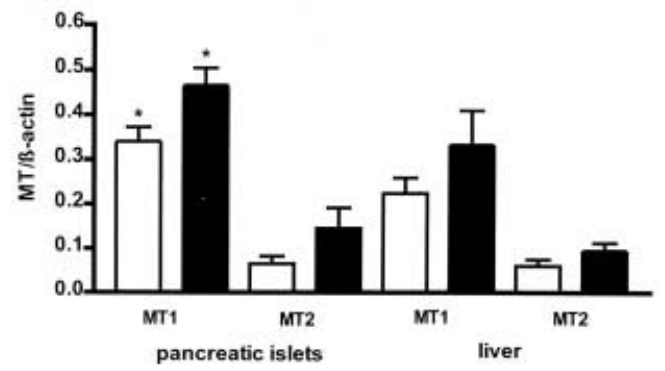

Fig. 5A-D. RT-PCR determination of MT-1, MT- 2 and $\beta$-actin mRNA in islets isolated from pancreata and liver of mice that had received $\mathrm{Zn}^{2+}$-enriched drinking water for 7 days or were not treated. RT-PCR products of $\mathrm{C} 57 \mathrm{BL} / 6 \mathbf{A}$ and $\mathrm{B} 6 \mathrm{SJL} / \mathrm{F}_{1} \mathbf{C}$ mice. Means \pm SEM of the ratios of MT- 1 to $\beta$-actin and MT- 2 to $\beta$-actin mRNA in isolated islets and liver of C57BL/6 B and $\mathrm{B} 6 \mathrm{SJL} / \mathrm{F}_{1} \mathbf{D}$ mice, which were treated with $\mathrm{Zn}^{2+}$-enriched drinking water $(\boldsymbol{\square})$ or were not treated $(\square)$. The values were calculated from three independent experiments. In general, treatment of mice with $\mathrm{Zn}^{2+}$-enriched drinking water modestly increased the mRNA expression of MT-1 and MT-2, a significant $(* p<0.05$ between the marked groups) induction, however, was only observed for MT-1 in pancreatic islets of $\mathrm{B} 6 \mathrm{SJL} / \mathrm{F}_{1}$ mice

ment with MLD-STZ induced a continuous increment of the mean autoantibody concentration with time, a significant difference $(p<0.05)$ was, however, observed only 4 weeks after treatment when compared with the control value.

\section{Discussion}

In our study, treatment with $\mathrm{Zn}^{2+}$-enriched drinking water prevented diabetes induced with MLD-STZ in $\mathrm{C} 57 \mathrm{BL} / 6$ and $\mathrm{B} 6 \mathrm{SJL} / \mathrm{F}_{1}$ mice. This effect was associated with a statistically significant up-regulation of MT protein and increment of mRNA expression of 
A

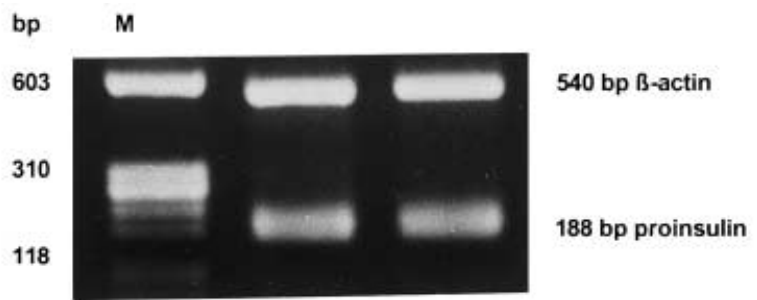

B

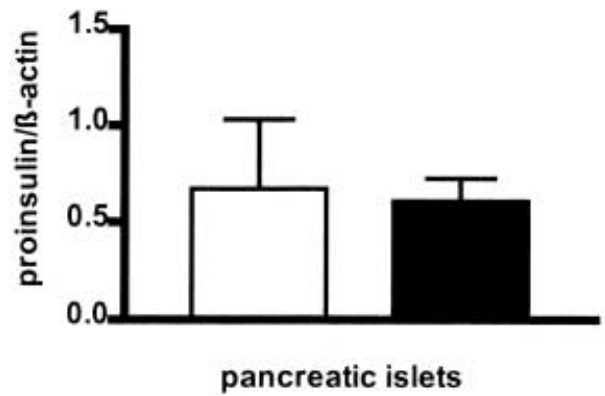

Fig. 6 A, B. RT-PCR determination of proinsulin mRNA in isolated islets of $\mathrm{C} 57 \mathrm{BL} / 6$ mice that had received $\mathrm{Zn}^{2+}$-enriched drinking water for 7 days or were not treated. Samples used for proinsulin mRNA were the same preparation as that used for MT-1 and MT-2 mRNA amplification. A RT-PCR products. B means \pm SEM of the ratios of proinsulin to $\beta$-actin mRNA in isolated islets of mice, which were treated with $\mathrm{Zn}^{2+}$ enriched drinking water $(\square)$ or were not treated $(\square)$. Treatment of mice with $\mathrm{Zn}^{2+}$-enriched drinking water failed to affect mRNA expression of proinsulin

the isoforms MT-1 and MT-2 in islets. Possibly, the slight increment of MT mRNA reflects mRNA stabilization facilitating more frequent translation with statistically significant MT protein production. Metallothionein were present in all islet cells including beta cells and prevailed in the cytoplasm whereas the exocrine cells stained only weakly.
These results extend previous findings from our laboratory [34, 35], using different experimental protocols. Injections of $\mathrm{Zn}^{2+}$ i.p. dose-dependently upregulated MT synthesis in islets [34] and protected against MLD-STZ diabetes [35]. In vitro, incubation of islets with $\mathrm{Zn}^{2+}$ also induced MT [33] and pre-incubation with $\mathrm{Zn}^{2+}$ protected against STZ toxicity [35]. In our present study, diabetes was prevented by giving $\mathrm{Zn}^{2+}$ orally, a route that is more suitable for longterm treatment than i.p. injections. Note the long prediabetic period of 10 weeks in $\mathrm{B} 6 \mathrm{SJL} / \mathrm{F}_{1}$ mice treated with MLD-STZ, which is five times that generally observed in other mouse strains [44]. These mice developed insulitis histologically similar to other mouse strains [44] that remained unaffected by treatment with $\mathrm{Zn}^{2+}$-enriched drinking water.

Discussing the mechanism underlying protection against MLD-STZ by $\mathrm{Zn}^{2+}$, we assumed that $\mathrm{Zn}^{2+}$-induced MT provides a defense against $\mathrm{OH}$ generated by MLD-STZ. This assumption is based on the following observations: ROS are increased during inflammatory reactions [3] and participate in beta-cell destruction [45]. Because T cell-dependent inflammatory reactions are also involved in diabetes induced by MLD-STZ [36, 46, 47], ROS could be generated and destroy beta cells. Of the group of ROS, OH are generated by the Fenton reaction from $\mathrm{H}_{2} \mathrm{O}_{2}$ in the presence of adventitious $\mathrm{Fe}^{2+}$. As MT scavenged $\mathrm{OH}$ in vitro $[20,22]$ they could also protect against it in vivo.

There is no evidence of $\mathrm{OH}$ liberation from STZ. It is, however, possible that STZ triggers the chain reaction to generate $\mathrm{OH}$ by interacting with respiring mitochondria or other cellular or subcellular fractions or both. Therefore, the production of $\mathrm{OH}$ in beta cells might occur in addition to the STZ-induced inflammatory reaction. In this context, we address the participation of reactive nitrogen species such as

Table 2. Effect of treatment with MLD-STZ and $\mathrm{Zn}^{2+}$-drinking water on infiltrations with mononuclear cells at pancreatic islet sites of $\mathrm{B} 6 \mathrm{SJL} / \mathrm{F}_{1}$ mice

\begin{tabular}{|c|c|c|c|c|c|c|c|c|c|}
\hline \multirow[t]{3}{*}{ Treatment of mice } & \multirow[t]{3}{*}{$\begin{array}{l}\text { Time point } \\
\text { of examination }\end{array}$} & \multicolumn{2}{|c|}{$\begin{array}{l}\text { Islet sites } \\
\text { examined }(n)\end{array}$} & \multicolumn{6}{|c|}{ Islets with mononuclear cell infiltrates, $n(\%)$} \\
\hline & & \multirow{2}{*}{$\begin{array}{l}\text { Islet } \\
\text { pole }\end{array}$} & \multirow{2}{*}{$\begin{array}{l}\text { Intra- } \\
\text { islet }\end{array}$} & \multicolumn{2}{|c|}{ At islet pole } & \multicolumn{4}{|c|}{ At intra-islet sites } \\
\hline & & & & Absent & Present & 0 & $1+$ & $2+$ & $3+$ \\
\hline- & 12 weeks old & 26 & 87 & $26(100)$ & $0(0)$ & $87(100)$ & $0(0)$ & $0(0)$ & $0(0)$ \\
\hline $\mathrm{Zn}^{2+}$-enriched drinking water & 18 weeks old & 7 & 339 & $5(71.4)$ & $2(28.6)$ & $331(97.6)$ & $5(1.5)$ & $1(0.3)$ & $1(0.3)$ \\
\hline MLD-STZ & $\begin{array}{l}10 \text { days after } \\
\text { the first injection }\end{array}$ & 106 & 284 & $63(59.4)$ & $43(40.6)$ & $258(90.8)$ & $10(3.5)$ & $5(1.8)$ & $7(2.5)$ \\
\hline MLD-STZ & $\begin{array}{l}4 \text { weeks after } \\
\text { the first injection }\end{array}$ & 134 & 462 & $69(51.5)$ & $65(48.5)$ & $380(82.2)$ & $42(9.1)$ & $18(3.9)$ & $17(3.7)$ \\
\hline $\begin{array}{l}\mathrm{Zn}^{2+} \text {-enriched drinking } \\
\text { water + MLD-STZ }\end{array}$ & $\begin{array}{l}10 \text { days after } \\
\text { the first injection }\end{array}$ & 43 & 349 & $19(44.2)$ & $24(55.8)$ & $291(83.4)$ & $19(5.4)$ & $4(1.1)$ & $4(1.1)$ \\
\hline $\begin{array}{l}\mathrm{Zn}^{2+} \text {-enriched drinking } \\
\text { water + MLD-STZ }\end{array}$ & $\begin{array}{l}4 \text { weeks after } \\
\text { the first injection }\end{array}$ & 59 & 357 & $28(47.5)$ & $31(52.5)$ & 314 (88.0) & $20(5.6)$ & $4(1.1)$ & $5(1.4)$ \\
\hline
\end{tabular}



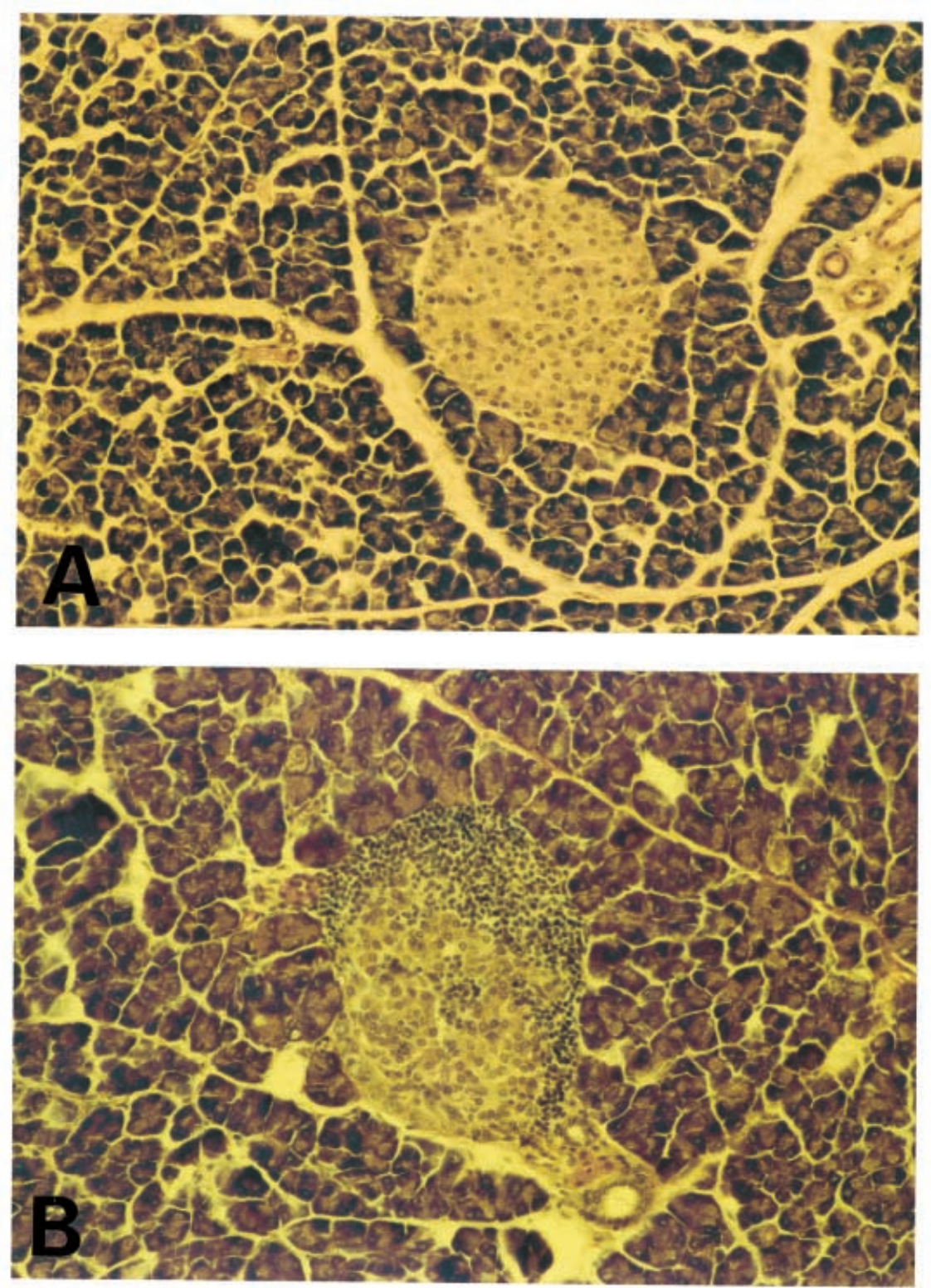

Fig. 7 A, B. Representative histology of pancreatic sections prepared from $\mathrm{B} 6 \mathrm{SJL} / \mathrm{F}_{1}$ mice and stained with haematoxylin and eosin. A no infiltrates of mononuclear cells in islets of untreated control mice. B intra-islet infiltrates scored as $2+$ of MLD-STZ-treated mice 4 weeks after the first injection with MLD-STZ. Original magnification $\times 200$

$\mathrm{NO}^{\circ}$ as mediators of beta-cell toxicity. Results of investigations focussing on the role of $\mathrm{NO}^{-}$in beta-cell destruction are contradictory. In vitro, NO produced by activated macrophages destroyed beta cells [48, 49]. In vivo, inhibition of NO generation prevented diabetes induced by MLD-STZ [5, 50]. Other investigators, in contrast, neither observed NO generation in islets isolated from mice treated with MLD-STZ [51] nor prevented diabetes induced by MLD-STZ with inhibitors of NO generation [52]. When generated, NO probably synergizes with ROS for beta-cell destruction. The interaction of $\mathrm{NO}^{-}$with $\mathrm{O}_{2}{ }^{--}$forms peroxynitrite, which can decompose to $\mathrm{OH}[53,54]$. In cell-free systems, STZ failed to liberate NO by spontaneous decomposition [55]. The exact mechanism underlying STZ-mediated beta-cell injury is not known because the effect of $\mathrm{NO}^{\circ}$ as a direct mediator of STZ-induced beta-cell toxicity has not been unequivocally proved.

We propose that the underlying mechanisms for the results obtained with $\mathrm{Zn}^{2+}$-enriched drinking water were that either MT up-regulated by $\mathrm{Zn}^{2+}$ scavenged $\mathrm{OH}$ generated by STZ in beta cells or by inflammatory reactions induced by MLD-STZ or both or that MT prevented $\mathrm{OH}$ generation by inhibiting the Fenton reaction through binding of $\mathrm{Fe}^{2+}$ [56]. It is unlikely that $\mathrm{Zn}^{2+}$ was the protecting element. Although $\mathrm{Zn}^{2+}$ is required for insulin production and insulin action [57], it failed to affect mRNA expression of proinsulin in mice (present data) and mRNA ex- 
pression of insulin in rats [28] or to lower the blood glucose concentrations due to increased insulin release (present data).

Treatment with $\mathrm{Zn}^{2+}$-enriched drinking water statistically significantly up-regulated MT synthesis in pancreatic islets and protected mice from diabetes induced by MLD-STZ. A variant of the classic MLDSTZ diabetes model has been observed in $\mathrm{B} 6 \mathrm{SJL} / \mathrm{F}_{1}$ mice with a prolonged prediabetic period of 10 weeks. This extended prediabetic phase could involve pathogenic pathways similar to those observed in human Type I diabetes. Because the dose of $\mathrm{Zn}^{2+}$ used was non-toxic, interventions with $\mathrm{Zn}$ salts can also be considered for other models of Type I diabetes and for humans at risk of developing this disease.

Acknowledgements. This work was supported by the German Research Foundation SFB 503 "Molecular and Cellular Mediators of Exogeneous Noxae", project B5 and by the Ministry for Health, Bonn, Germany.

\section{References}

1. Verge CF, Gianani R, Yu L et al. (1995) Late progression to diabetes and evidence for chronic $\beta$-cell autoimmunity in identical twins of patients with type I diabetes. Diabetes 44: 1176-1179

2. Wilson SB, Kent SC, Patton KT et al. (1998) Extreme Th1 bias of invariant $\mathrm{V} \alpha 24 \mathrm{~J} \alpha \mathrm{Q} \mathrm{T}$ cells in type 1 diabetes. Nature 391: 177-181

3. Halliwell B (1994) Free radicals, antioxidants and human disease: curiosity, cause, or consequence? Lancet 344: 721-724

4. Mendola J, Wright JR, Lacy PE (1989) Oxygen free radical scavengers and immune destruction of murine islets in allograft rejection and multiple low-dose streptozotocin. Diabetes 38: 379-385

5. Lukic ML, Stosic-Grujicic S, Ostojic N, Chan WL, Liew FY (1991) Inhibition of nitric oxide generation affects the induction of diabetes by streptozotocin in mice. Biochem Biophys Res Commun 178: 913-920

6. Corbett JA, McDaniel ML (1992) Does nitric oxide mediate autoimmune destruction of beta cells? Possible therapeutic interventions in IDDM. Diabetes 41: 897-903

7. Kolb H, Kolb-Bachhofen V (1992) Type I (insulin-dependent) diabetes mellitus and nitric oxide. Diabetologia 35: 796-797

8. Rabinovitch A, Suarez WL, Power RF (1992) Combination therapy with an antioxidant and a corticosteroid prevents autoimmune diabetes in NOD mice. Life Sci 51: 1937-1943

9. Horio F, Fukuda M, Katoh H et al. (1994) Reactive oxygen intermediates in autoimmune islet cell destruction of the NOD mouse induced by peritoneal exudate cells (rich in macrophages) but not T cells. Diabetologia 37: 22-31

10. Wu G (1995) Nitric oxide synthesis and the effect of aminoguanidine and $N^{\mathrm{G}}$-monomethyl-L-arginine on the onset of diabetes in the spontaneously diabetic BB rat. Diabetes 44: $360-364$

11. Lau A, Ramanathan S, Poussier P (1998) Excessive production of nitric oxide by macrophages from DP-BB rats is secondary to the T-lymphopenic state of these animals. Diabetes 47: 197-205
12. Cadenas E, Boveris A, Ragan CI, Stoppani AO (1977) Production of superoxide radicals and hydrogen peroxide by $\mathrm{NADH}$-ubiquinone reductase and ubiquinol-cytochrom $\mathrm{C}$ reductase from beef-heart mitochondria. Arch Biochem Biophys 180: 248-257

13. Wakeyama H, Takestige $\mathrm{K}$, Takayanagi R, Minakami S (1982) Superoxide-forming NADPH oxidase preparation of pig polymorphonuclear leukocytes. Biochem J 205: 593-601

14. Sato M, Bremner I (1993) Oxygen free radicals and metallothionein. Free Radic Biol Med 14: 325-337

15. Tiedge M, Lortz S, Drinkgern J, Lenzen S (1997) Relation between antioxidant enzyme gene expression and antioxidative defense status of insulin-producing cells. Diabetes 46: $1733-1742$

16. Tiedge M, Lortz S, Munday R, Lenzen S (1998) Complementary action of antioxidant enzymes in the protection of bioengineered insulin-producing RINm5F cells against the toxicity of reactive oxygen species. Diabetes 47: $1578-1585$

17. Kubisch HM, Wang J, Luche R et al. (1994) Transgenic copper/zinc superoxide dismutase modulates susceptibility to type 1 diabetes. Proc Natl Acad Sci USA 91: 9956-9959

18. Kubisch HM, Wang J, Bray TM, Phillips JP (1997) Targeted overexpression of $\mathrm{Cu} / \mathrm{Zn}$ superoxide dismutase protects pancreatic beta cells against oxidative stress. Diabetes 46: 1563-1566

19. Hamer DH (1986) Metallothionein. Ann Rev Biochem 55: 913-951

20. Thornalley PJ, Vasak M (1985) Possible role for metallothionein in protection against radiation-induced oxidative stress. Kinetics and mechanism of its reaction with superoxide and hydroxyl-radicals. Biochim Biophys Acta 827:36-44

21. Chubatsu LS, Meneghini R (1993) Metallothionein protects DNA from oxidative damage. Biochem J 291: 193-198

22. Kumari MV, Hiramatsu M, Ebadi M (1998) Free radical scavenging actions of metallothionein isoforms I and II. Free Radic Res 29: 93-101

23. Abel J, de Ruiter N (1989) Inhibition of hydroxyl-radicalgenerated DNA degradation by metallothionein. Toxicol Lett 47: 191-196

24. Miura T, Muraoka S, Ogiso T (1997) Antioxidant activity of metallothionein compared with reduced glutathione. Life Sci 60: PL301-PL309

25. Palmiter RD (1993) Metallothionein genes and their regulation in transgenic mice. In: Suzuki KT, Imura N, Kimura M (eds) Metallothionein III: Biological roles and medical implications. Birkhäuser-Verlag, Berlin, pp 399-406

26. Andrews GK (1990) Regulation of metallothionein gene expression. Prog Food Nutr Sci 14: 193-258

27. Onosaka S, Min KS, Fujita Y, Tanaka K, Iguchi S, Okada Y (1988) High concentration of pancreatic metallothionein in normal mice. Toxicology 50: 27-35

28. Andrews GK, Kage K, Palmiter-Thomas P, Sarras MP Jr (1990) Metal ions induce expression of metallothionein in pancreatic exocrine and endocrine cells. Pancreas 5: $548-554$

29. Baumann JW, Liu J, Liu P, Klaassen CD (1991) Increase in metallothionein produced by chemicals that induce oxidative stress. Toxicol Appl Pharmacol 110: 347-354

30. Yang J, Cherian MG (1994) Protective effects of metallothionein on streptozotocin-induced diabetes in rats. Life Sci 55: 43-51

31. De Lisle RC, Sarras MP Jr, Hidalgo J, Andrews GK (1996) Metallothionein is a component of exocrine pancreas se- 
cretion: implications for zinc homeostasis. Am J Physiol 271: C1103-C1110

32. Onosaka S, Cherian MG (1982) Comparison of metallothionein determination by polarographie and cadmium-saturation methods. Toxicol Appl Pharmacol 63: 270-274

33. Ohly P, Gleichmann H (1995) Metallothionein: in vitro induction with zinc and streptozotocin in pancreatic islets of mice. Exp Clin Endocrinol Diabetes 103: 79-82

34. Zimny S, Gogolin F, Abel J, Gleichmann H (1993) Metallothionein in isolated pancreatic islets of mice: induction by zinc and streptozotocin, a naturally occurring diabetogen. Arch Toxicol 67: 61-65

35. Ohly P, Wang Z, Abel J, Gleichmann H (1998) Zincsulphate induced metallothionein in pancreatic islets and protected against the diabetogenic toxin streptozotocin. Talanta 46: 355-359

36. Like AA, Rossini AA (1976) Streptozotocin-induced pancreatic insulitis: new model of diabetes mellitus. Science 193: 415-417

37. Winge DR, Miklossy KA (1982) Domain nature of metallothionein. J Biol Chem 257: 3471-3476

38. Wang Z, Dohle C, Friemann J, Green BS, Gleichmann H (1993) Prevention of high- and low-dose STZ-induced diabetes with D-glucose and 5-thio-D-glucose. Diabetes 42: 420-428

39. Seissler J, de Sonnaville JJ, Morgenthaler NG et al. (1998) Immunological heterogeneity in type I diabetes: presence of distinct autoantibody patterns in patients with acute onset and slowly progressive disease. Diabetologia 41: 891-897

40. Chomczynski P, Sacchi N (1987) Singlestep method of RNA isolation by acid guanidium thiocyanate-phenolchloroform extraction. Anal Biochem 162: 156-159

41. Watson CJ, Demmer J (1995) Procedures for cDNA cloning. In: Glover DM, Hames BB (eds) DNA cloning 1 Core Techniques. Oxford University Press, New York, pp 83-119

42. Vallee BL, Falchuk KH (1993) The biochemical basis of zinc physiology. Physiol Rev 73: 79-118

43. Wong FS, Janeway CA Jr (1999) Insulin-dependent diabetes and its animal models. Curr Opin Immunol 11: 643-647

44. Wilson GL, Leiter EH (1990) Streptozotocin interactions with pancreatic $\beta$-cells and the induction of insulin-dependent diabetes. In: Dyrberg T (ed) Current Topics in Microbiology and Immunology. Springer-Verlag, Berlin, pp $27-54$
45. Oberley LW (1988) Free radicals and diabetes. Free Radic Biol Med 5: 113-124

46. Elias D, Prigozin H, Polak N, Papoport M, Lohse AW, Cohen IR (1994) Autoimmune diabetes induced by the $\beta$-cell toxin STZ: Immunity to the $60-\mathrm{kDa}$ heat shock protein and to insulin. Diabetes 43: 1273-1280

47. Klinkhammer C, Popowa P, Gleichmann H (1988) Specific immunity to streptozotocin: cellular requirements for induction of lymphoproliferation. Diabetes 37: 74-80

48. Kröncke KD, Kolb-Bachofen V, Berschick B, Burkart V, Kolb H (1991) Activated macrophages kill pancreatic syngeneic islet cells via arginine-dependent nitric oxide generation. Biochem Biophys Res Commun 175: 752-758

49. Kröncke KD, Fehsel K, Sommer A, Rodriguez ML, KolbBachofen V (1995) Nitric oxide generation during cellular metabolization of the diabetogenic N-methyl-N-nitrosourea streptozotocin contributes to islet cell DNA damage. Biol Chem 376: 179-185

50. Kolb H, Kiesel U, Kröncke KD, Kolb-Bachofen V (1991) Suppression of low dose streptozotocin induced diabetes in mice by administration of nitric oxide synthase inhibitor. Life Sci 49: 213-217

51. Papaccio G, Pisanti FA, Latronico MV, Ammendola E, Galdieri M (2000) Multiple low-dose and single high-dose treatments with streptozotocin do not generate nitric oxide. J Cell Biochem 77: 82-91

52. Sternesjö J, Welsh N, Sandler S (1997) S-Methyl-L-Thiocitrulline counteracts interleukin $1 \beta$ induced suppression of pancreatic islet function in vitro, but does not protect against multiple low-dose streptozotocin-induced diabetes in vivo. Cytokine 9: 352-359

53. Beckman JS, Beckman TW, Chen J, Marshall PA, Freeman BA (1990) Apparent hydroxyl radical production by peroxynitrite: Implications for endothelial injury from nitric oxide and superoxide. Proc Natl Acad Sci USA 87: 1620-1624

54. Halliwell B, Gutteridge JM, Cross CE (1992) Free radicals, antioxidants, and human disease. J Lab Clin Med 119: 598-620

55. Kröncke KD, Kolb-Bachofen V (1996) Streptozotocin is not a spontaneous NO donor. Free Radic Res 24: 77-80

56. Good M, Vasak M (1986) Iron(II)-substituted metallothionein: evidence for the existence of iron-thiolate clusters. Biochemistry 25: 8353-8356

57. Huber AM, Gershoff SN (1973) Effect of zinc deficiency in rats on insulin release from the pancreas. J Nutr 103: 1739-1744 